\title{
Conclusion: Three Reflections
}

'Conventional theology assumes that the different religions must necessarily oppose each other . . . But on reaching full maturity the human spirit aspires to rise above every manner of conflict and opposition, and a person then recognises all expressions of the spiritual life as an organic whole ... There will remain a decided difference in the qualities of the different faiths and in the values of one as compared with another. From the entire ensemble there will automatically become manifest the central essence which is at the heart of all faiths.'

Abraham Isaac Kook, Talelei Orot pp. 17ff (apud Ben Zion Bokser, The Jewish Mystical Tradition (New York: The Pilgrim Press, 1981) p. 266).

'There is but one and the same God who, from the beginning to the end and by various dispensations, comes to the rescue of mankind.'

St Irenaeus, Adversus Haereses, III, 12, 13.

'The lamps are different, but the Light is the same: it comes from Beyond.'

Jalālu'l-Din Rūmī, 'The One True Light' (Math. III, 1259). 